\title{
Ultimate Failure Resistance of Concrete with Partial Replacements of Sand by Polycarbonate Plastic Waste Under Impact Load
}

\author{
Mustafa Maher Al-Tayeb $^{1 *} \quad$ Ismail Al Daoor $^{1} \quad$ Sulaiman R. Wafi ${ }^{1} \quad$ B. A. Tayeh ${ }^{2}$ \\ 1.School College of Applied Engineering and Urban Planning, University of Palestine, PO Box 1075, Gaza, \\ Palestine \\ 2.Civil Engineering Department, The Islamic University of Gaza, Gaza, Palestine
}

\begin{abstract}
Disposal of waste polycarbonate plastic is a serious environmental issue all around the globe, on account of its health hazard and difficulty in land filling. As a possible solution to the problem of polycarbonate plastic waste, an experimental study was conducted to examine the potential of using it as sand replacement in the concrete. This paper examines impact strength properties of concrete in which different amounts $2.5 \%, 5 \%$ and $10 \%$ of polycarbonate plastic waste particles were used as sand replacement. For each amount, six beams of $100 \mathrm{~mm} \times 100$ $\mathrm{mm} \times 500 \mathrm{~mm}$ were subjected to $4.5 \mathrm{~kg}$ hammer from $480 \mathrm{~mm}$ height. The number of blows of the hammer required to induce the ultimate failure of the beams were recorded. The results are presented in terms of impact energy required for the ultimate failure. The concrete mixtures exhibited ability to absorb a large amount of impact energy. The polycarbonate plastic waste increased the ultimate failure impact energy of concrete.
\end{abstract}

Keywords: Polycarbonate plastic waste; Cement concrete; Compressive strength; Ultimate failure impact energy. DOI: $10.7176 / \mathrm{CER} / 12-2-06$

Publication date: February $29^{\text {th }} 2020$

\section{Introduction}

Disposal of waste plastic is a serious environmental issue all around the globe, on account of its health hazard and difficulty in land filling. The high cost of disposal and the requirement of large landfill area often result in random and illegal dumping of waste plastic. Hence, there is an urgent need to identify alternative solutions to reuse the plastic waste for other applications, and concrete has been identified to be one of the feasible options $[1,2]$. This is in line with fundamental environmental strategies; prevention of waste, recycling of waste materials, escaping landfill, energy regaining from waste, and saving raw materials [3]. On the other hand, the concrete has limited properties such as low tensile strength, low ductility, and low impact energy absorption [4]. There are many concrete components and structures subject to impact loads, for instance, wall panels, bridge decks, hydraulic structures, and industrial floors, airport pavements, highway paving. Therefore, higher resistance to impact loads and load carrying capacity are required in this kind of applications [5-6]. In regards to the said matter, Mohammadhosseini, et al. [7-9] reported that fibre reinforced composites have the ability to address the brittleness of concrete. Utilization of waste metalized plastic fibres in the production of concrete has revealed possibility towards the sustainable and green construction with a benefit of the harmless alternative of waste plastics disposal [7]. In their studies, , Mohammadhosseini, et al. [7] worked on the reinforced concrete with waste metalized plastic fibres. They found that adding these waste fibres could have significant effects on development of strength and impact resistance of concrete composites.

Different types of plastic have been investigated these last years: polyethylene terephthalate (PET), highdensity polyethylene (HDPE) and polypropylene (PP). These studies have focussed on the effect of plastic addition in the workability of the fresh composites and in the mechanical strength of the hardened mixtures [10-12].

Ismail and AL-Hashmi [13] have found that, as the percentage of waste plastic (consists of $80 \%$ polyethylene and $20 \%$ polystyrene) increases, the workability increases and the bulk density decreases. This last result is due to the low density of plastic aggregates comparing to conventional ones. Naik et al. [14] have found that postconsumer waste HDPE plastic can be successfully used in concrete as soft filler. They have shown that chemical treatment has a significant effect on performance of the plastic filler in concrete. AL-Manaseer and Dalal [15] stated that concrete containing plastic aggregates from car bumpers has more ductile behavior than similar types of concrete made with conventional aggregates. This ductile behaviour could be very advantageous in minimizing crack formation in concrete structures. Also, the compressive strength and the splitting tensile strength of the concrete decreased when the amount of plastics aggregates increased. Benazzouk et al. [16] and other [17-27] have investigated the physical and mechanical properties of cement composites containing shredded rubber waste. The results have shown that the presence of air voids and rubber particles in the matrix reduces the dynamic elastic modulus, which indicates a high level of sound insulation. Al-Tayeb et al. [28] investigated the effect of partial replacements of sand by waste rubber on the fracture characteristics of concrete. They found that addition of waste tire in concrete enhanced the fracture properties, while both compressive and flexural strengths were decreased. 
Al-Tayeb et al. [29-31] conducted tests to examine the performance of rubberized concrete with $5 \%, 10 \%$ and $20 \%$ replacements by volume of sand by waste crumb rubber under static and impact load conditions. Their results showed that the addition of rubber improved the impact load behavior of concrete.

However, the mechanical properties of concrete with partial replacements of sand by polycarbonate plastic waste under impact load are yet to be explored. In this study, effects of partial replacements of sand by polycarbonate plastic waste on the performance of concrete under low velocity impact loading were investigated. Specimens were prepared for $2.5 \%, 5 \%$ and $10 \%$ replacements by volume sand. For each case, six cubes of 100 $\mathrm{mm} \times 100 \mathrm{~mm} \times 500 \mathrm{~mm}$ were subjected to $4.5 \mathrm{~kg}$ hammer from $457 \mathrm{~mm}$ height. The number of blows of the hammer required to induce the ultimate failure of the beam were recorded.

\section{Materials and methods}

\subsection{Materials}

For the development of the present research, conventional concrete compounds were prepared with type I ordinary Portland cement. The cement chemical compositions are presented in Table 1.

Table 1: Chemical compositions of cement

\begin{tabular}{cc}
\hline Item & Percentage in Cement (\%) \\
\hline \multicolumn{3}{c}{ Oxide compositions } \\
\hline $\mathrm{SiO} 3$ & 19.98 \\
\hline $\mathrm{A} 2 \mathrm{O} 3$ & 5.17 \\
\hline $\mathrm{Fe} 2 \mathrm{O} 3$ & 3.27 \\
\hline $\mathrm{CaO}$ & 64.17 \\
\hline $\mathrm{MgO}$ & 0.79 \\
\hline $\mathrm{SO} 3$ & 2.38 \\
\hline Total alkalis & 0.90 \\
\hline Insoluble Residue & 0.20 \\
\hline Loss on Ignition & 2.50 \\
\hline & Mineral compositions \\
\hline $\mathrm{C} 3 \mathrm{~S}$ & 63.13 \\
\hline $\mathrm{C} 2 \mathrm{~S}$ & 9.61 \\
\hline $\mathrm{C} 3 \mathrm{~A}$ & 8.18 \\
\hline $\mathrm{C} 3 \mathrm{AF}$ & 9.94
\end{tabular}

The maximum coarse aggregate size was $10 \mathrm{~mm}$, and the fine aggregate was graded natural silica sand. The specific gravities of fine and coarse aggregates were 2.64and 2.62 respectively. Concrete mixes were prepared with replacements of sand volume by $2.5,5$, and $10 \%$ with plastic waste. The particle size distribution of polycarbonate plastic waste is given in Table 2 .

Table 2: Particle size distribution of sand and polycarbonate plastic waste

\begin{tabular}{lcc}
\hline Sieve size $(\mathrm{mm})$ & \multicolumn{2}{c}{ Cumulative passing $(\%)$} \\
\cline { 2 - 3 } & Sand & Polycarbonate plastic waste \\
\hline 5 & 100 & 100 \\
3.15 & 76 & 24 \\
2.36 & 42 & 4.2 \\
1.18 & 19 & 0.9 \\
0.6 & 6 & 0 \\
0.3 & 1 & 0 \\
\hline
\end{tabular}

The composition of normal concrete is presented in Table 3.

The compositions of the plastic waste concrete are presented in Table 4. Figure 1 show the images of plastic waste sample (relative density, 0.8) used in the present study. 


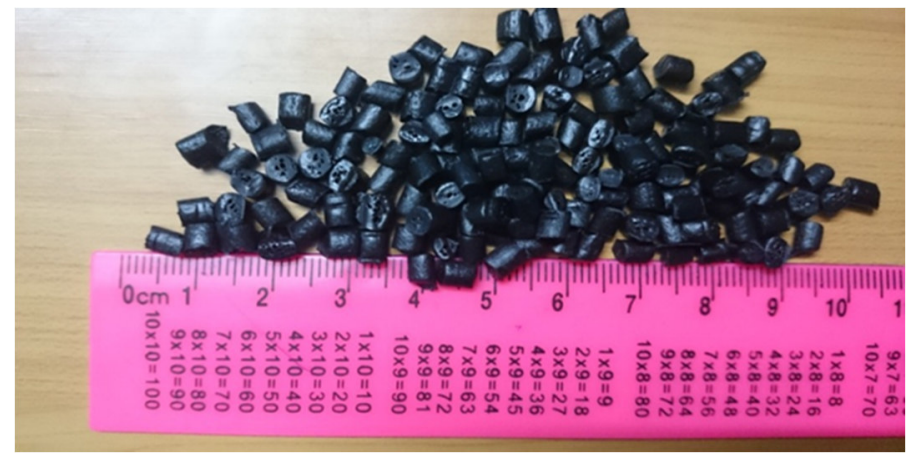

Figure 1: Images of the plastic waste.

Table 3: Mixture properties of normal concrete

\begin{tabular}{ccccc}
\hline Unit & Cement & Water & $\begin{array}{c}\text { Fine } \\
\text { aggregate }\end{array}$ & $\begin{array}{c}\text { Coarse } \\
\text { aggregate }\end{array}$ \\
\hline Weight $(\mathrm{kg})$ & 454 & 195 & 670 & 1072 \\
Volume $\left(\mathrm{m}^{3}\right)$ & 144 & 195 & 251 & 405 \\
\hline
\end{tabular}

Table 4: Mixture properties of powder plastic concrete

\begin{tabular}{ccccccc}
\hline Unit & $\begin{array}{c}\text { Plastic } \\
\text { percent }\end{array}$ & Cement & Water & $\begin{array}{c}\text { Fine } \\
\text { aggregate }\end{array}$ & $\begin{array}{c}\text { Coarse } \\
\text { aggregate }\end{array}$ & $\begin{array}{c}\text { Plastic } \\
\text { waste }\end{array}$ \\
\hline Weight $(\mathrm{kg})$ & - & 454 & 195 & 654 & 1072 & 5.0 \\
Volume $\left(\mathrm{m}^{3}\right)$ & $2.5 \%$ & 144 & 195 & 245 & 405 & 6.0 \\
Weight $\left(\mathrm{kg}^{3}\right)$ & - & 454 & 195 & 638 & 1072 & 10.0 \\
Volume $\left(\mathrm{m}^{3}\right)$ & $5 \%$ & 144 & 195 & 239 & 405 & 12.5 \\
Weight $\left(\mathrm{kg}^{3}\right)$ & - & 454 & 195 & 603 & 1072 & 20.1 \\
Volume $\left(\mathrm{m}^{3}\right)$ & $10 \%$ & 144 & 195 & 226 & 405 & 25.1 \\
\hline
\end{tabular}

For the compression test, three cubic specimens of $100 \mathrm{~mm}$ side were prepared for each type. For split-tensile test, three cylinders of $160 \mathrm{~mm}$ height and $100 \mathrm{~mm}$ diameter were prepared with the aforementioned proportions of polycarbonate plastic waste. In the case of impact test, 6 specimens of $100 \mathrm{~mm} \times 100 \mathrm{~mm} \times 500 \mathrm{~mm}$ beams were prepared for each type. All specimens were cured in water for 28 days in accordance with ASTM C 192/C192M$98[32]$.

\subsection{Experimental set-up and procedure}

Figure 2 shows the hammer of modified proctor which was used as drop weight machine to investigate the impact resistance of plastic concrete.

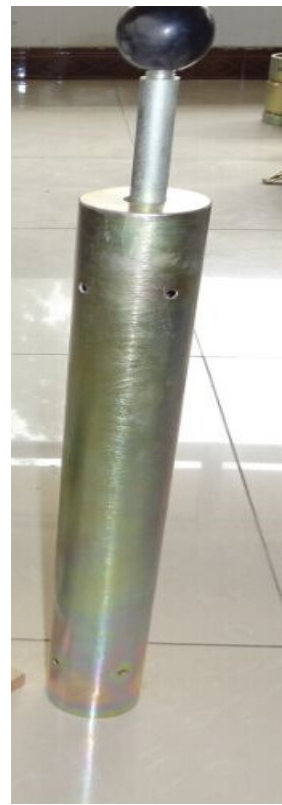

Fig. 2: Hammer of modified proctor.

For impact test, 6 specimens of $100 \mathrm{~mm} \times 100 \mathrm{~mm} \times 500 \mathrm{~mm}$ beams were prepared for each type. A $4.5 \mathrm{~kg}$ 
hammer $51 \mathrm{~mm}$ in diameter with a circular flat face was raised to $457 \mathrm{~mm}$ above the specimen, and then released by following the procedure Mohammadi et al. [33]. The hammer was dropped repeatedly and the number of blows required to produce the ultimate failure in the specimens were recorded. The impact energy (U) imparted by the hammer for ' $n$ ' number of bows with mass of hammer $(\mathrm{m})$ and a hammer velocity ' $v$ ' was calculated as follows:
$\mathrm{U}=n * 1 / 2\left(\mathrm{~m} v^{2}\right)$
$v=\sqrt{2 *(0.9 g) * h}$
(1) where,

$\mathrm{g}=$ gravitational acceleration and $=$ drop height of hammer. The factor, 0.9 accounts for effect of the air resistance and friction between the hammer and the guide rails [34].

\section{Results and discussion}

\subsection{Slump test}

One of the problems when adding plastic waste into the concrete is the reduction of workability of the concrete. Therefore, Superplasticizer with $1 \%$ was added to solve this problem. The procedure of slump test was according to ASTM C143 [35]. As shown in Figure 3 the slump of the concrete decreases with increase in plastic content. As $10 \%$ of sand volume is replaced by plastic waste, the slump reduces to $40 \mathrm{~mm}$ only where it still within the designed slump for this concrete $(30-60 \mathrm{~mm})$. The reduction of the slump with increase in the amount of plastic particles in the concrete might be attributed to the increase in the interior voids and the rough surface of the plastic particles which might result in increasing friction between the fresh concrete ingredients. Generally, superplasticizer produced the same electrostatic charges on the cement particles surface. This resulted in the repulsion among the cement particles, prevented the coagulation and minimized the interior voids and the friction between the fresh concrete ingredients.

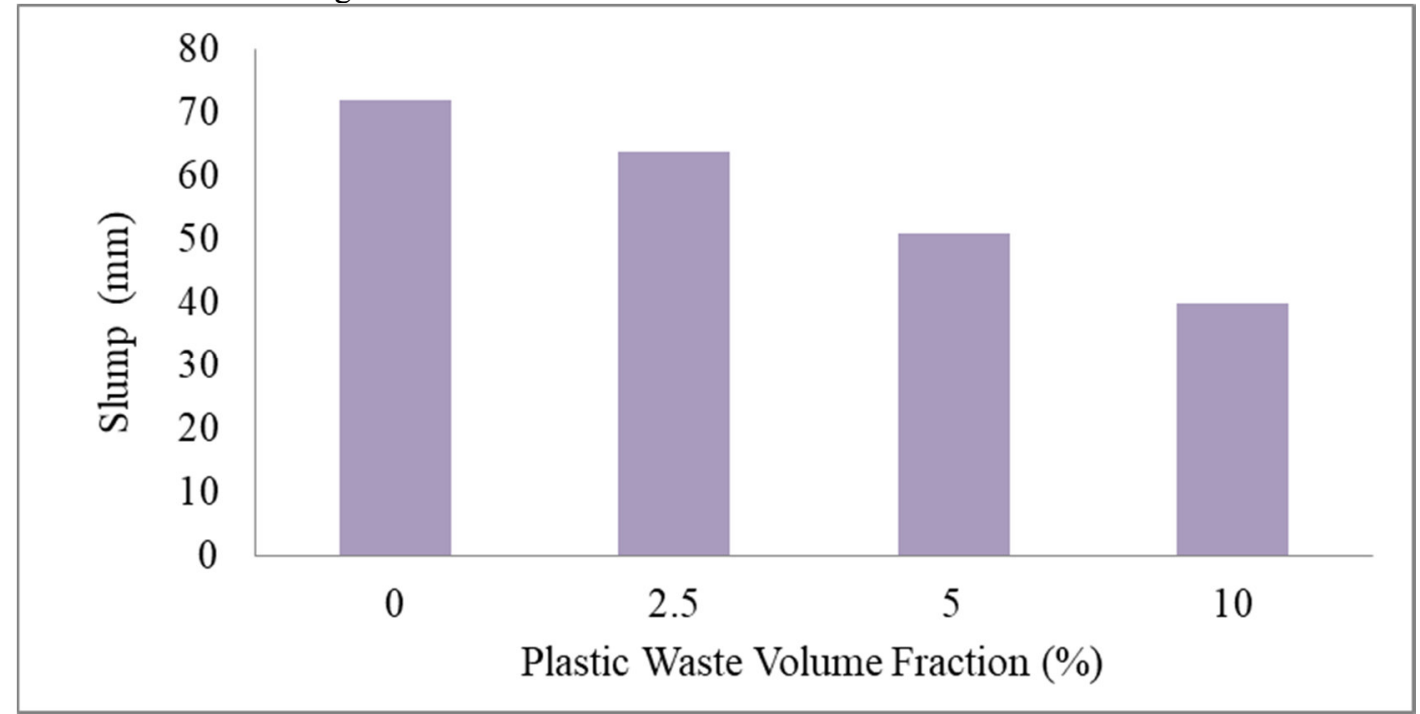

Fig. 3: Effect of sand replacement ratio on slump of plastic concrete

\subsection{Compressive stress and modulus of elasticity}

The compressive strength and modulus of elasticity were tested according to ASTM C 39 [36] and ASTM C 469 [37]. The results presented in Table 5 show a systematic reduction in concrete compressive strength with the increase of plastic content. The initial 28-day compressive strength of almost 43.7 MPa decreased to about 27.6 MPa when $10 \%$ replacement of sand by plastic waste was made. The compressive stress are reduced by 14,33 and $37 \%$ with the sand replacement by plastic by $2.5,5$, and $10 \%$ of volumes, respectively. Similar is the case of elastic modulus which reduces by 2,11 and $21 \%$.

Although strength reduction is certainly a negative property that may hinder the use of plastic waste, elastic modulus results appear the positive effect in the form of the failure mode. The results sustained a much higher deformation than the control mix. With plastic content $10 \%$, the samples exhibited significant elastic deformation, which was retained on unloading. Thus, flexibility and ability to deform elastically is increased significantly.

The reduction of compressive stress of concrete is attributed to the weak compressive stress of the plastic particles compared to the compressive stress of the natural sand. In addition to that the weak bond between plastic particles and the cement paste and the deformability of the plastic particles, which result in the initiation of cracks around the plastic particles in a fashion similar to that, occur in normal concrete due to air voids, cause reduction in stress. This reduction may also be due to grading, as the particle size of sand used in this research was smaller than the particle size of the plastic waste which increased the voids between the aggregate. 
Table 5: Compressive strength and modulus of elasticity

\begin{tabular}{ccc}
\hline $\begin{array}{c}\text { Plastic } \\
\text { percent } \\
\%\end{array}$ & $\begin{array}{l}\text { Average } \\
\text { compressive } \\
\text { stress (Mpa) }\end{array}$ & $\begin{array}{l}\text { Average elastic modulus } \\
\left(\mathrm{kN} / \mathrm{mm}^{2}\right)\end{array}$ \\
\hline $0 \%$ & 43.7 & 31.1 \\
\hline $2.5 \%$ & 37.2 & 30.5 \\
\hline $5 \%$ & 29.3 & 27.8 \\
\hline $10 \%$ & 27.6 & 24.7 \\
\hline
\end{tabular}

For split-tensile test, three cylinders of $160 \mathrm{~mm}$ height and $100 \mathrm{~mm}$ diameter were used for each concrete mixture. The test was carried out in accordance with the procedures stated in the ASTM C 496 standard [38]. Fig .4 shows the result of splitting-tensile test, which indicates that the plain concrete is yielded at $3.8 \mathrm{MPa}$, while with the coarse aggregate replacement $(2.5,5$, and $10 \%$ of volumes) by plastic waste it is reduced by 16,29 and $42 \%$ respectively. This is also consistent with the result of compression stress. Further, the reduction in tensile strength is lower than that in compression strength.

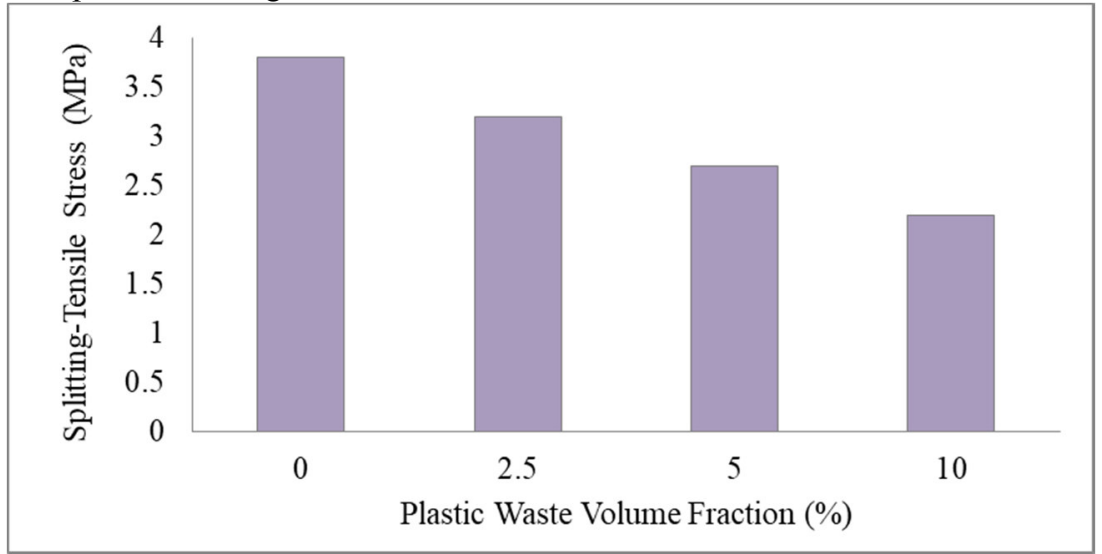

Fig. 4: Splitting tensile stress against volume fraction of plastic waste.

\subsection{Impact test}

Six concrete beams of each type of mixtures were prepared for this test. The tested beams were $100 \mathrm{~mm} \times 100 \mathrm{~mm}$ $\times 500 \mathrm{~mm}$. The numbers of impact blows required for producing the ultimate failure, for each type of concrete specimen were recorded in Table 6, and the corresponding plot is shown in Figs. 5.

Figs. 6 present the results in terms of ultimate failure impact energy. The results show that the ultimate failure resistance increases by 37,53 and $68 \%$ with $2.5,5$, and $10 \%$ of plastic replacements respectively. The enhanced ultimate failure impact resistance is due to the enhanced flexibility of the composite mix by the addition of plastic. The increases in flexibility are attributed to the high ductility of plastic which when added to the concrete, improves the mix ductility [30] and the ability to absorb the impact load. 
Table 5: Impact test results for plain and plastic concrete.

\begin{tabular}{|c|c|c|c|c|c|}
\hline $\begin{array}{c}\text { Type } \\
\text { of } \\
\text { concrete }\end{array}$ & $\begin{array}{c}\text { Plastic } \\
(\%)\end{array}$ & $\begin{array}{l}\text { No. of blows of } \\
\text { ultimate failure }\end{array}$ & $\begin{array}{l}\text { Average no. of } \\
\text { blows }\end{array}$ & $\begin{array}{c}\text { Impact energy } \\
(\mathrm{kN} \mathrm{mm}) \\
\text { of ultimate failure }\end{array}$ & $\begin{array}{l}\text { Average impact } \\
\text { energy }(\mathrm{kN} \mathrm{mm})\end{array}$ \\
\hline \multirow[t]{6}{*}{ Plain } & 0 & 102 & \multirow[t]{6}{*}{95.8} & 1851.1 & \multirow[t]{6}{*}{1739.1} \\
\hline & 0 & 125 & & 2268.5 & \\
\hline & 0 & 97 & & 1760.3 & \\
\hline & 0 & 85 & & 1542.5 & \\
\hline & 0 & 72 & & 1306.6 & \\
\hline & 0 & 94 & & 1705.9 & \\
\hline \multirow{18}{*}{$\begin{array}{l}\text { Coarse } \\
\text { aggregate } \\
\text { replaced } \\
\text { with } \\
\text { plastic } \\
\text { waste }\end{array}$} & $5 \%$ & 136 & \multirow[t]{6}{*}{131.2} & 2468.1 & \multirow[t]{6}{*}{2380.4} \\
\hline & $5 \%$ & 92 & & 1669.6 & \\
\hline & $5 \%$ & 165 & & 2994.4 & \\
\hline & $5 \%$ & 170 & & 3085.1 & \\
\hline & $5 \%$ & 94 & & 1705.9 & \\
\hline & $5 \%$ & 130 & & 2359.2 & \\
\hline & $10 \%$ & 94 & \multirow[t]{6}{*}{147.0} & 1705.9 & \multirow[t]{6}{*}{2667.7} \\
\hline & $10 \%$ & 261 & & 4736.5 & \\
\hline & $10 \%$ & 172 & & 3121.4 & \\
\hline & $10 \%$ & 109 & & 1978.1 & \\
\hline & $10 \%$ & 78 & & 1415.5 & \\
\hline & $10 \%$ & 168 & & 3048.8 & \\
\hline & $15 \%$ & 270 & \multirow[t]{6}{*}{160.7} & 4899.9 & \multirow[t]{6}{*}{2915.7} \\
\hline & $15 \%$ & 120 & & 2177.7 & \\
\hline & $15 \%$ & 112 & & 2032.5 & \\
\hline & $15 \%$ & 198 & & 3593.2 & \\
\hline & $15 \%$ & 92 & & 1669.6 & \\
\hline & $15 \%$ & 172 & & 3121.4 & \\
\hline
\end{tabular}

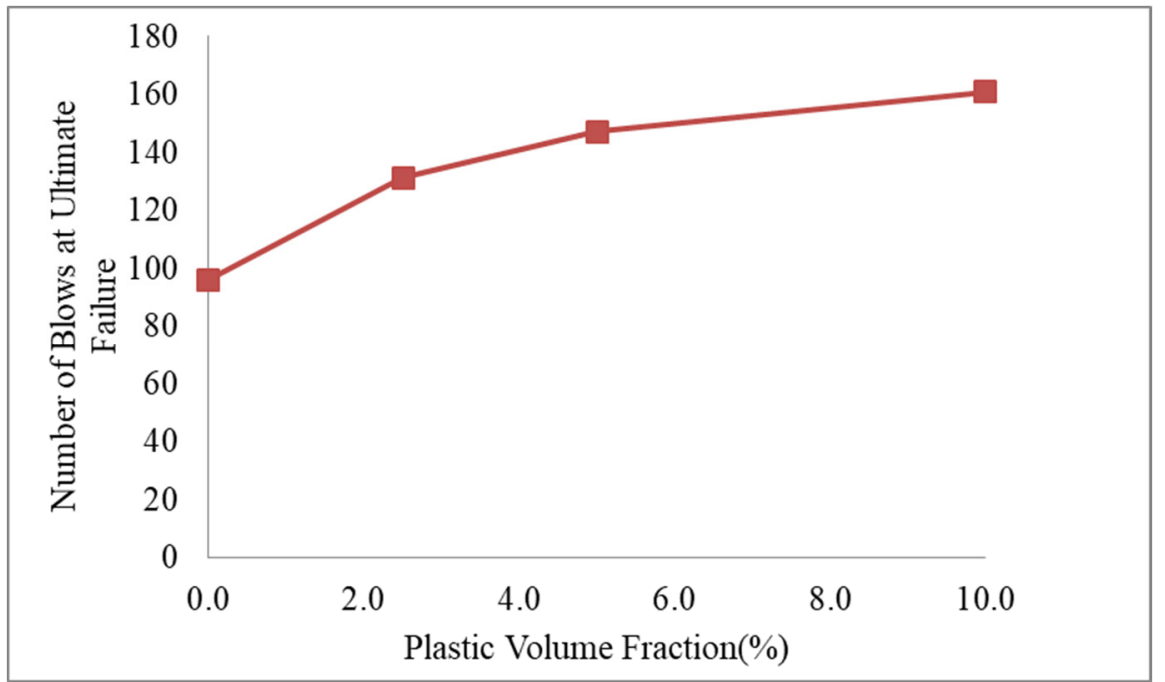

Fig. 5: Ultimate failure impact resistance against volume fraction of plastic. 


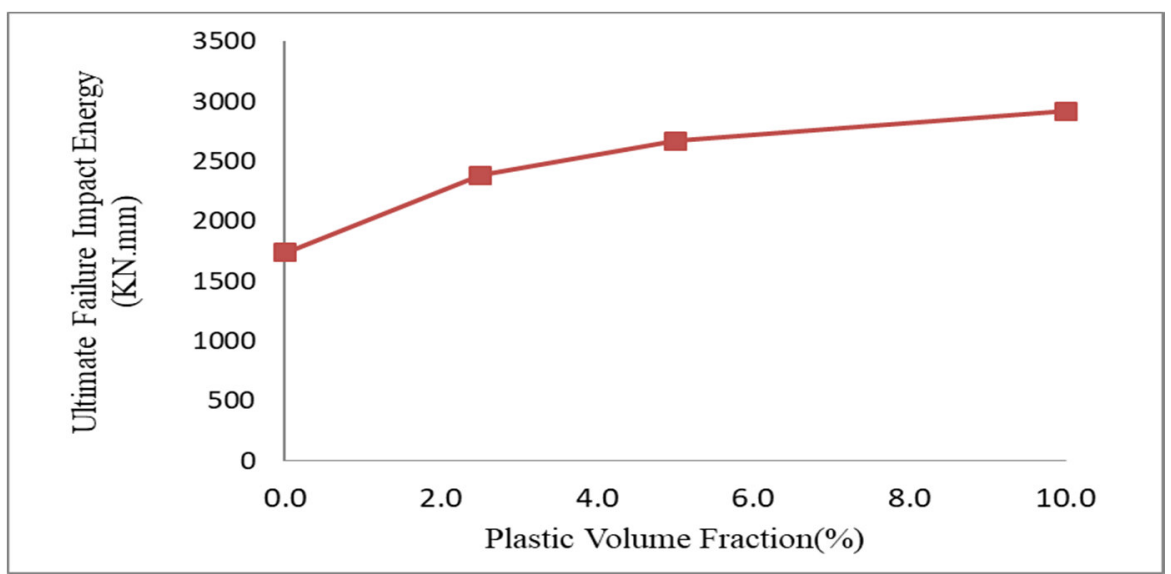

Fig. 6: Ultimate failure impact energy against volume fraction of plastic.

\section{Conclusion}

This study examined how different volume fractions of polycarbonate plastic waste affect the mechanical properties of concrete under static and impact load. The following conclusions were found:

- The slump of the plastic concrete decreases with increase in plastic content. Superplasticizer with $1 \%$ will solve this problem.

- The results show that the compressive stress and modulus of elasticity decrease with increase in plastic content.

- The results show that the splitting-tensile stress decreases with increase in plastic content.

- The ultimate failure resistance increases by 37,53 and $68 \%$ with $2.5,5$, and $10 \%$ of plastic replacements respectively. The enhanced ultimate failure impact resistance is due to the enhanced flexibility of the composite mix by the addition of plastic.

\section{Acknowledgment}

The author would like to thank the undergraduate students, Abdulaziz M. El-Hadad, Deaa J. El-Mashhrawi and Khaled W. El-Salhy for their assistance in the work.

\section{Reference}

[1] R. Siddique, J. Khatib, I. Kaur, Use of recycled plastic in concrete: a review, Waste Manage. 28 (10) (2008) $1835-1852$.

[2] N. Saikia, J. de Brito, Use of plastic waste as aggregate in cement mortar and concrete preparation: a review, Constr. Build. Mater. 34 (2012) 385-401.Wang

[3] B. Bhardwaj, P. Kumar, Waste foundry sand in concrete: a review, Constr. Build. Mater. 156 (2017) 661-674.

[4] S. Akçaözog lu, C.D. Atis, K. Akçaözog lu, An investigation on the use of shredded waste PET bottles as aggregate in lightweight concrete, Waste Manage. (Oxford) 30 (2) (2010) 285-290.

[5] MoEU, Information received during the Eionet consultation of the paper, Email of 14 November 2012 from Arzu Nuray, Turkish Ministry of Environment and Urbanisation, 2012.

[6] Hasan, Hayder Alaa, M. Neaz Sheikh, and Muhammad NS Hadi. "Maximum axial load carrying capacity of Fibre Reinforced-Polymer (FRP) bar reinforced concrete columns under axial compression." Structures. Vol. 19. Elsevier, 2019.

[7] Mohammadhosseini, Hossein, Mahmood Md Tahir, and Abdul Rahman Mohd Sam. "The feasibility of improving impact resistance and strength properties of sustainable concrete composites by adding waste metalized plastic fibres." Construction and Building Materials 169 (2018): 223-236.

[8] Mohammadhosseini, Hossein, ASM Abdul Awal, and Jamaludin B. Mohd Yatim. "The impact resistance and mechanical properties of concrete reinforced with waste polypropylene carpet fibres." Construction and Building Materials 143 (2017): 147-157.

[9] Mohammadhosseini, H., Tahir, M. M., Sam, A. R. M., Lim, N. H. A. S., \& Samadi, M. "Enhanced performance for aggressive environments of green concrete composites reinforced with waste carpet fibers and palm oil fuel ash." Journal of cleaner production 185 (2018): 252-265.

[10] Choi, Y.W., Moon, D.J., Chung, J.S., Cho, S.K., 2005. Effects of waste PET bottles aggregate on properties of concrete. Cem. Concr. Res 35 (4), 776-781.

[11] Yazoghli-Marzouk, O., Dheilly, R.M., Queneudec, M., 2007. Valorization of postconsumer waste plastic in cementitious concrete composites. Waste manage. 27 (2), 310-318.

[12] Sobhan, K.H., Mashna, M., 2002. Tensile strength and toughness of soil-cement-flyash composite reinforced 
with recycled high-density polyethylene strips. J. Mater. Civ. Eng. 14 (2), 177-184.

[13] Ismail, Z.Z., AL-Hashmi, E.A., 2008. Use of waste plastic in concrete mixture as aggregate replacement. Waste Manage. 28 (11), 2041-2047.

[14] Naik, T.R., Singh, S.S., Huber, C.O., Brodersen, B.S., 1996. Use of post-consumer waste plastics in cementbased composites. Cem. Concr. Res. 26 (10), 1489-1492.

[15] AL-Manaseer, A.A., Dalal, T.R., 1997. Concrete containing plastic aggregates. Concr. Int. 19 (8), 47-52.

[16]Benazzouk, A., Douzane, O., Mezreb, K., Quéneudec, M., 2006. Physico-mechanical properties of aerated cement composites containing shredded rubber waste. Cem. Concr. Comp. 28 (7), 650-657.

[17] A. Al-Manaseer, T. Dalal, Concrete containing plastic aggregates, Concr. Int. 19 (1997) 47-52.

[18] Mermerdaş, Kasım, et al. "Effect of aggregate properties on the mechanical and absorption characteristics of geopolymer mortar." Engineering Science and Technology, an International Journal 20.6 (2017): 1642-1652.

[19] P. Soroushian, J.S. Plasencia, S. Ravanbakhsh, Assessment of reinforcing effects of recycled plastic and paper in concrete, ACI Mater. J. 100 (2003) 203-207.

[20] A. Kan, R. Demirboga, A novel material for lightweight concrete production, Cem. Concr. Compos. 31 (2009) $489-495$.

[21]A. Kan, R. Demirboga, A new technique of processing for waste-expanded polystyrene foams as aggregates, J. Mater. Process. Techno. 209 (2009) 2994-3000.

[22] P. Asokan, M. Osmani, A.D.F. Price, Improvement of the mechanical properties of glass fibre reinforced plastic waste powder filled concrete, Constr. Build. Mater. 24 (2010) 448-460.

[23] Azo. Build, Avoidance of waste: beneficial use of industrial by-products as constituents of concrete (The third information sheet prepared by the environmental working party of the concrete society's material group), Concrete 37 (5) (2003) 43-45.

[24] S. As'ad, P. Gunawan, M. Alaydrus, Fresh state behavior of self compacting concrete containing waste material fibres, The Twelfth East Asia-Pacific Conference on Structural Engineering and Construction, Proc. Eng. 14 (2011) 797-804.

[25]P. Soroushian, F. Mirza, A. Alhozaimy, Permeability characteristics of polypropylene fiber reinforced concrete, ACI Mater. J. 92 (3) (1995) 291-295.

[26] S. Hinıslioglu, E. Agar, Use of waste density polyethylene as bitumen modifier in asphalt concrete mix, Mater. Lett. 58 (2004) 267-271.

[27]L. Pezzi, P. De Luca, D. Vuono, F. Chiappetta, A. Nastro, Concrete products with waste's plastic material (bottle, glass, plate), Mater. Sci. Forum 514 (2) (2006) 1753-1757.

[28]Al-Tayeb , M.M. ; Abu Bakar , B. H. ; Akil , H.M. ; Ismail , H. Effect of partial replacements of sand and cement by waste rubber on the fracture characteristics of concrete. Polym.-Plast. Technol. Eng. 2012 , 51 (6), 583-589.

[29] Al-Tayeb M.M, Abu Bakar B.H, Ismail. H, and Akil. H.M, Effect of partial replacement of sand by recycled fine crumb rubber on the performance of hybrid rubberized-normal concrete under impact load: experiment and simulation. Journal of Cleaner Production. 2013, 59 (15), 284-289

[30] Al-Tayeb, M. M., Ismail, H., Dawoud, O., Wafi, S. R., \& Al Daoor, I. (2017). Ultimate failure resistance of concrete with partial replacements of sand by waste plastic of vehicles under impact load. International Journal of Sustainable Built Environment, 6(2), 610-616.

[31] Al-Tayeb, M. M., Abu Bakar, B. H., Ismail, H., \& Akil, H. M. (2013). Impact Energy for the First Crack of Reinforced Concrete with Partial Replacements of Sand by Fine Crumb Rubber. In Advanced Materials Research Vol. 701, pp. 286-290

[32] American Society for Testing and Materials (ASTM) C192/192. Standard practice for making and curing concrete test specimens in the laboratory, vol. 4.02, West Conshohocken, PA, USA; (2006).

[33] Mohammadi , Y. ; Carkon-Azad , R. ; Singh , S.P. ; Kaushik , S.K. Impact resistance of steel fibrous concrete containing fibres of mixed aspect ratio. Constr. Build. Mater. 2009 , 23 (1), 183-189.

[34] Xu , H. Specialized fiber reinforced concretes under static and impact loading, $\mathrm{PhD}$ thesis, University of British Columbia, Heritage Branch, Canada (1987).

[35] American Society for Testing and Materials (ASTM) C143. Standard Test Method for Slump of Hydraulic Cement Concrete', vol. 04.02, 1995., West Conshohocken, PA, USA.

[36] American Society for Testing and Materials (ASTM) C39/C39 M-01, Test Method for Compressive Strength of Cylindrical Concrete Specimens, Annual Book of ASTM Standards, Pennsylvania (2001).

[37] American Society for Testing and Materials (ASTM) C469-94, Standard Test Method for Static Modulus of Elasticity and Poisson's Ratio of Concrete in Compression, Annual Book of ASTM Standards, Pennsylvania (1994).

[38] ASTM, C. 496, Standard test method for splitting tensile strength of cylindrical concrete specimens. United States: ASTM International, 2004. 